\title{
RECENT INCREASES IN AIR POLLUTION: EVIDENCE AND IMPLICATIONS FOR MORTALITY
}

\author{
Karen Clay \\ Nicholas Z. Muller \\ Working Paper 26381 \\ http://www.nber.org/papers/w26381 \\ NATIONAL BUREAU OF ECONOMIC RESEARCH \\ 1050 Massachusetts Avenue \\ Cambridge, MA 02138 \\ October 2019
}

The authors thank Severin Borenstein, Akshaya Jha, Brian Kovak, Daniel Nagin, Joseph Shapiro, Lowell Taylor, Xiao Wang and participants in the HILS seminar at CMU. Karen Clay acknowledges financial support provided by Heinz College at Carnegie Mellon. The views expressed herein are those of the authors and do not necessarily reflect the views of the National Bureau of Economic Research.

NBER working papers are circulated for discussion and comment purposes. They have not been peer-reviewed or been subject to the review by the NBER Board of Directors that accompanies official NBER publications.

(C) 2019 by Karen Clay and Nicholas Z. Muller. All rights reserved. Short sections of text, not to exceed two paragraphs, may be quoted without explicit permission provided that full credit, including $(\odot$ notice, is given to the source. 
Recent Increases in Air Pollution: Evidence and Implications for Mortality

Karen Clay and Nicholas Z. Muller

NBER Working Paper No. 26381

October 2019

JEL No. I10,Q51,Q52,Q53,Q54

\begin{abstract}
$\underline{\text { ABSTRACT }}$
After declining by 24.2\% from 2009 to 2016, annual average fine particulate matter (PM2.5) in the United States in counties with monitors increased by $5.5 \%$ between 2016 and 2018. Increases occurred in multiple census regions and in counties that were in and out of attainment with National Ambient Air Quality Standards (NAAQS). We explore channels through which the increase may have occurred including increases in economic activity, increases in wildfires, and decreases in Clean Air Act enforcement actions. The health implications of this increase in PM2.5 between 2016 and 2018 are significant. The increase was associated with 9,700 additional premature deaths in 2018. At conventional valuations, these deaths represent damages of $\$ 89$ billion.
\end{abstract}

\author{
Karen Clay \\ Heinz College \\ Carnegie Mellon University \\ 5000 Forbes Avenue \\ Pittsburgh, PA 15213 \\ and NBER \\ kclay@andrew.cmu.edu \\ Nicholas Z. Muller \\ Department of Engineering, and Public Policy \\ Tepper School of Business \\ Carnegie Mellon University \\ 4215 Tepper Quad \\ 5000 Forbes Avenue \\ Pittsburgh, PA 15213 \\ and NBER \\ nicholas.muller74@gmail.com
}




\section{Introduction}

After a decade of improvement, annual average fine particulate matter $\left(\mathrm{PM}_{2.5}\right)$ in the United States increased in 2017 and again in 2018. These increases are worrisome, because previous studies have shown that $\mathrm{PM}_{2.5}$ increases premature mortality risk. This risk comprises the largest share of monetary damages from air pollution (United States Environmental Protection Agency, 1999, 2010a; Muller, Mendelsohn and Nordhaus, 2011).

Drawing on data for 2009-2018, this paper documents trends in $\mathrm{PM}_{2.5}$ and the implications of these trends for mortality. Nationally, $\mathrm{PM}_{2.5}$ levels fell by $24.2 \%$ from 2009 to 2016 and then increased 5.5\% from 2016 to 2018. $\mathrm{PM}_{2.5}$ increased at monitors in the West and Midwest census regions and was flat in Northeast and South census regions. Increases occurred in counties that were in and out of attainment with National Ambient Air Quality Standards (NAAQS).

The paper explores channels through which the increases may have occurred, including increases in economic activity, increases in wildfires, and decreases in Clean Air Act enforcement actions. The evidence suggests that all three may have played roles in the observed increase. Different types of economic activity are associated with different subspecies of $\mathrm{PM}_{2.5}$. Trends in these subspecies are consistent with decreases in consumption of coal, increases in consumption of natural gas, and increases in fuel consumption by vehicles. For wildfires, omitting key wildfire months lowers the magnitude of the observed increases in $\mathrm{PM}_{2.5}$ in the West and Midwest from 2016 to 2018. The overall pattern of decline from 2009 to 2016 and then reversal, however, remains the same. The most frequent type of EPA Clean Air Act enforcement action that results in a penalty are 113d actions. 113d actions with penalties fell from 2009 to 2016 and continued to fall from 2016 to 2018 in both attainment and nonattainment counties.

While the causes of the increase in $\mathrm{PM}_{2.5}$ warrant further research, it is important to note that the documented increases in $\mathrm{PM}_{2.5}$ have health consequences. From 2016 to 2018, premature deaths from $\mathrm{PM}_{2.5}$ rose by 9,700 . At conventional valuations, these deaths represent damages of $\$ 89$ billion (in $\$ 2016$ ). 


\section{Data amd Empirical Approach}

Data are from the Air Quality System (AQS) database of daily monitored readings provided by United States Environmental Protection Agency (2019a). These data include total $\mathrm{PM}_{2.5}$ and three major species of $\mathrm{PM}_{2.5}$, ammonium nitrate, sulfate, and elemental carbon. Figure 1 shows the location of the 653 counties with monitors in our sample. The data encompass all observations in the contiguous United States from 2009 to 2018. This yields a dataset of over 1.8 million daily readings. NAAQS attainment status and histories are provided by United States Environmental Protection Agency (2019c). The analysis examines two definitions of nonattainment: nonattainment with standards relevant to $\mathrm{PM}_{2.5}$ levels including nitrogen dioxide, sulfur dioxide, and $\mathrm{PM}_{2.5}$ and nonattainment with any criteria pollutant.

Our primary empirical specification is:

$$
\ln \left(P M_{j, m, d, t}\right)=\alpha_{j}+\gamma_{m}+\delta_{d}+\beta_{t}+\epsilon_{j, m, d, t}
$$

The dependent variable is the natural $\log$ of $\mathrm{PM}_{2.5}$ (or its subspecies). It includes pollution monitor $(\mathrm{j})$, month of year $(\mathrm{m})$, day of month $(\mathrm{d})$, and year $(\mathrm{t})$ fixed effects. Standard errors are clustered at the monitor level.

\section{Trends in $\mathbf{P M}_{2.5}$}

Figure 2 and column 1 of Table 1 show that the decline in $\mathrm{PM}_{2.5}$ pollution levels ended in 2016 and was followed by increases in 2017 and 2018. The aggregate decline from 2009 to 2016 was $24.2 \%$. By 2018, it had rebounded by 5.5\% from its 2016 low. The annual average $\mathrm{PM}_{2.5}$ level across all monitors in 2016 was $7.51 \mu \mathrm{g} / \mathrm{m}^{3}$. Appendix Table A.1 provides means for 2016 for outcomes in the regression tables and figures.

Figure 3 and columns 2-5 of Table 1 show that $\mathrm{PM}_{2.5}$ pollution levels in all four Census regions stopped declining in 2016. Over 2016 to 2018, the Northeast and South census 
regions saw no change in $\mathrm{PM}_{2.5}$, while the Midwest and West regions saw increases of 9.3\% and 11.5\%. The average $\mathrm{PM}_{2.5}$ levels in 2016 for the Northeast, Midwest, South, and West were: $7.50,7.19,8.09$, and $7.34 \mu \mathrm{g} / \mathrm{m}^{3}$. The patterns are similar in Appendix Table A.2, which is weighted by county population in 2016 .

Ambient air quality is managed under by the Clean Air Act primarily though the National Ambient Air Quality Standards (NAAQS). Counties are classified annually as being in or out of attainment with the NAAQS for the six criteria pollutants. In our main specification, we consider a county in nonattainment if it is in nonattainment for $\mathrm{PM}_{2.5}$ or either of two precursor species, $\mathrm{SO}_{2}$ and $\mathrm{NO}_{2}$. In alternative specifications, we consider a county in nonattainment if it is in nonattainment for any criteria pollutant.

Figure 4 and columns 1 and 2 of Table 2 show that $\mathrm{PM}_{2.5}$ began to increase after 2016 for monitors located in both attainment and nonattainment counties. The aggregate decline from 2009 to 2016 was $21.7 \%$ in nonattainment counties and $23.9 \%$ in attainment counties. Between 2016 and 2018, pollution levels increased $8.1 \%$ in nonattainment counties and $4.9 \%$ in attainment counties. The average $\mathrm{PM}_{2.5}$ levels in 2016 for nonattainment and attainment counties were: 8.73 and $7.05 \mu \mathrm{g} / \mathrm{m}^{3}$. Columns 3 and 4 of Table 2 present results if nonattainment is defined as a county that is out of attainment for any of the criteria pollutants. The results are similar under this broader classification.

\section{Economic Activity, Wildfires, and Enforcement}

This section provides evidence on three possible channels through which the recent increase may have occurred: economic activity, wildfires, and enforcement.

\subsection{Economic Activity}

To shed light on economic activity, we use speciated $\mathrm{PM}_{2.5}$ data, which consists of nitrate, sulfate, and elemental carbon. These species are useful for understanding the sources of pollution, because different processes emit different types of pollutants (United States 
Environmental Protection Agency, 1998). For example, oxides of nitrogen (precursors to particulate nitrate) are emitted by industrial, household, and mobile sources. Sulfur dioxide is predominantly emitted by coal-fired power plants (Zhang et al., 2014). In contrast, natural gas-fired power plants emit only trace amounts of sulfur dioxide. Elemental carbon is emitted by diesel vehicles, coal fired power plants, and other industrial sources that utilize coal or fuel oil.

Figure 5 and Table 3 show that sulfate, nitrate, and elemental carbon declined steeply from 2009 to 2016. From 2016 to 2018, sulfate continued to fall by $9.0 \%$. In contrast, nitrate increased by $7.4 \%$ and elemental carbon rose by $20.7 \%$. The average levels in 2016 for sulfate, nitrate, and elemental carbon were: $0.76,0.55$, and $0.33 \mu \mathrm{g} / \mathrm{m}^{3}$.

The chemical composition of particulates point to increased use of natural gas and to vehicle miles traveled as likely contributors to the increase in $\mathrm{PM}_{2.5}$. Sulfate has declined, which is consistent with the decline in coal fired power generation and increasing use of flue-gas desulfurization in remaining plants. From 2009 to 2018, coal consumption by the electricity sector fell by 31.9\% (Energy Information Administration, 2019a). The increase in nitrate is consistent with observed increases in natural gas consumption by households, power plants, and industry. Natural gas consumption during this period grew $30.1 \%$ overall and consumption by the electricity sector rose $54.6 \%$ (Energy Information Administration, 2019b). From 2009 to 2018, vehicle miles increased by about 10\% (Federal Highway Administration, 2019). Elemental carbon is primarily emitted when diesel fuel oil or biomass is burned. The pattern in Figure 5 for elemental carbon is robust to exclusion of summer wildfire months. Therefore, we conclude that the effect is due to diesel vehicles, as well as some industrial boilers.

\subsection{Wildfires}

Wildfires are another possible cause of the increase in $\mathrm{PM}_{2.5}$. Borgschulte, Molitor and Zou (2018) show that fires frequently occur in the West and affect air quality in the Midwest. Table 4 and Appendix Table A.3 examine the possible importance of wildfires 
for the West, the Midwest, and for California by omitting June to September - the main wildfire season. ${ }^{1}$ We include California, because as we shall see later, it accounts for a large share of the increase in premature mortality in both years. The last column omits November in California, because there were two major wildfires in November 2018, the Camp and Woolsey fires.

The results in Table 4 and Appendix Table A.3 suggest that wildfires may account for some of the observed increase in $\mathrm{PM}_{2.5}$ from 2016 to 2018, but not for the general pattern of decline and then reversal. For example, in Table 4 over 2009-2016 when June to September are dropped, $\mathrm{PM}_{2.5}$ at the average monitor in the West decreased $23.5 \%$, in the Midwest decreased 29.0\%, and in California decreased 27.6\%. It then increased from 2016 to 2018 by $4.9 \%$ in the West, $4.2 \%$ in the Midwest, and $12.5 \%$ in California.

\subsection{Enforcement}

Enforcement may influence firms' compliance with the Clean Air Act. To explore enforcement, we us the EPA's ECHO database. The database includes many different types of enforcement actions, not just those pertaining to air pollution. We report trends in enforcement actions targeting the Clean Air Act. More specifically, we focus on those actions resulting in a penalty for violations of section $113 \mathrm{~d}$ of the Act. These are the most frequent type of action targeting the Clean Air Act and resulting in a penalty. Over 3,000 such measures have been reported in the ECHO database since 2009.

Figure 6 shows that 113d enforcement actions resulting in a penalty have been quite variable over time and have fallen from 2013 to 2018. Figure 7 provides graphs for counties by attainment status, where nonattainment refers to $\mathrm{PM}_{2.5}, \mathrm{SO}_{2}$, or $\mathrm{NO}_{2}$. Enforcement actions in attainment counties are similar to the patterns in Figure 6 - a decline from 2013 on. Enforcement actions in nonattainment counties declined dramatically over time, especially since 2012. These declines could have been driven by many factors including increased compliance levels or changes in enforcement practices. The decline in enforce-

\footnotetext{
${ }^{1}$ This is an imperfect solution, since some of the pollution during these months may come from increases in driving or increased use of electricity for air conditioning.
} 
ment actions, however, is concerning in light of the increases in air pollution in both attainment and nonattainment counties after $2016 .^{2}$

\section{Implications for Mortality}

To explore the public health consequences of the increase in $\mathrm{PM}_{2.5}$, we employ the damage function approach used in EPA's Benefit-Cost Analyses of the Clean Air Act (United States Environmental Protection Agency, 1999, 2010a), the Regulatory Impact Analyses for $\mathrm{PM}_{2.5}$ (United States Environmental Protection Agency, 2010b), and numerous academic studies (Muller, Mendelsohn and Nordhaus, 2011; Muller, 2014). This strategy uses peer-reviewed epidemiological dose-response functions that link exposure to ambient $\mathrm{PM}_{2.5}$ to elevated mortality rates (Krewski et al., 2009), along with vital statistics (population and mortality rates), by county. Further details on this calculation are in Appendix B.

Table 5 presents the increases in annual deaths and damages from 2016 to 2017 and from 2016 to 2018. The number of premature deaths due to $\mathrm{PM}_{2.5}$ in counties with monitors increased by about 4,900 from 2016 to 2017 and 9,700 from 2016 to 2018. Valuation of mortality risk employs the Value of a Statistical Life (VSL) approach.(Viscusi and Aldy, 2003) We employ the EPA's preferred VSL of $\$ 7.4$ million, which we then convert to 2016 dollars (United States Environmental Protection Agency, 2019b) Applying the VSL to these effects produces damages of $\$ 45$ billion and $\$ 89$ billion.

About $80 \%$ of the burden of air pollution is borne by the elderly. While some deaths among the elderly are shifted by days or weeks, recent research suggests that the burden is "concentrated among the elderly with five to ten years of remaining life expectancy, followed by those with two to five years remaining, because these groups represent a large

\footnotetext{
${ }^{2}$ Interviews suggest that declines in federal enforcement may adversely affect state enforcement (Volcovici, 2019). Cynthia Giles, former head of the EPA's Office of Enforcement and Compliance Assurance, wrote in April 2017: "Don't be fooled by the suggestion that if the EPA walks away, everything will still be fine because states will step to the plate and enforce the law. The EPA's retreat will only embolden industry and weaken states. If the EPA is not there to enforce laws, then in many cases no one will (Giles, 2017)."
} 
fraction of the Medicare population and are also vulnerable to acute particulate matter exposure (Deryugina et al., 2019)."

The ambient monitoring data suggest that $\mathrm{PM}_{2.5}$ increases were especially pronounced in California. In 2016, the readings across the state averaged $8.06 \mu \mathrm{g} / \mathrm{m}^{3}$. This increased to $9.68 \mu \mathrm{g} / \mathrm{m}^{3}$ in 2017 , and $11.34 \mu \mathrm{g} / \mathrm{m}^{3}$ in 2018. Because of these large increases and the large exposed population in California, we find that nearly $43 \%$ of the increase in deaths nationally from 2016 to 2018 occurred in California. California experienced numerous large wildfires. Table 5 presents deaths for California and for California dropping June to September. In contrast to the results for the United States, the number of deaths is very similar whether or not June to September are included.

To further explore the influence of fires, we conducted an additional exercise in which ambient $\mathrm{PM}_{2.5}$ readings from every month in 2017 and 2018 were dropped from the annual average $\mathrm{PM}_{2.5}$ calculations. This exercise finds that November 2018 had an outsized effect on our mortality calculations. Without this month, the change in deaths from 2017 to 2018 in California was 590 compared to over 2,000 when observations from November 2018 are included. Importantly, the disastrous Camp Fire occurred during this month. No other month over the 2017 to 2018 time period in California has nearly as large an impact on our mortality calculations.

\section{Conclusion}

After a long period of decline, $\mathrm{PM}_{2.5}$ in counties with monitors in the United States increased by $5.5 \%$ between 2016 and 2018. Increases occurred in multiple census regions and in counties that were in and out of attainment with National Ambient Air Quality Standards (NAAQS). We examined evidence on economic activity, wildfires, and enforcement. The evidence is consistent with all three having contributed to the increase, although further research remains to be done on the relative effects of the three and on other causes. The increase in $\mathrm{PM}_{2.5}$ was associated with 9,700 additional premature deaths in 2018. At conventional valuations, these deaths represent damages of $\$ 89$ billion. The number 
of deaths and the damages highlight the importance of air pollution as a policy issue. 


\section{References}

Borgschulte, Mark, David Molitor, and Eric Zou. 2018. "Air Pollution and the Labor Market: Evidence from Wildfire Smoke." Working Paper.

Deryugina, Tatyana, Garth Heutel, Nolan H Miller, David Molitor, and Julian Reif. 2019. "The mortality and medical costs of air pollution: Evidence from changes in wind direction." National Bureau of Economic Research.

Energy Information Administration. 2019a. "Consumption for electricity generation, coal, United States, annual, retrieved from EIA."

Energy Information Administration. 2019b. "Natural Gas Consumption by End Use, retrieved from EIA." Data retrieved from: https://eia.gov/dnav/ng/ng_cons_sum_ dcu_nus_m".

Federal Highway Administration. 2019. "Vehicle Miles Traveled [TRFVOLUSM227NFWA]." Data retrieved from: https://fred.stlouisfed.org/series/ TRFVOLUSM227NFWA.

Giles, Cynthia. 2017. "Why we cant just leave environmental protection to the states." Grist. Available at: https://tinyurl.com/yyrcx9vl.

Krewski, Daniel, Michael Jerrett, Richard T Burnett, Renjun Ma, Edward Hughes, Yuanli Shi, Michelle C Turner, C Arden Pope III, George Thurston, Eugenia E Calle, et al. 2009. Extended follow-up and spatial analysis of the American Cancer Society study linking particulate air pollution and mortality. Health Effects Institute Boston, MA.

Muller, Nicholas Z. 2014. "Boosting GDP growth by accounting for the environment." Science, 345(6199): 873-874.

Muller, Nicholas Z, Robert Mendelsohn, and William Nordhaus. 2011. "Environmental accounting for pollution in the United States economy." American Economic Review, 101(5): 1649-75. 
United States Environmental Protection Agency. 1998. "Particulate Matter (PM2.5) Speciation Guidance Document." Available at: https://www3.epa.gov/ ttnamti1/files/ambient/pm25/spec/specpln2.pdf.

United States Environmental Protection Agency. 1999. "The Benefits and Costs of the Clean Air Act: 1990 to 2010." EPA-410-R99-001. Washington, DC: US Environmental Protection Agency, Office of Air and Radiation, Office of Air and Radiation: Office of Policy in Washington, DC.

United States Environmental Protection Agency. 2010a. "The Benefits and Costs of the Clean Air Act 1990 to 2020: EPA Report to Congress." Washington, DC: US Environmental Protection Agency, Office of Air and Radiation, Office of Air and Radiation: Office of Policy in Washington, DC.

United States Environmental Protection Agency. 2010b. "Regulatory Impact Analysis for the Proposed Federal Transport Rule." EPA-HQ-OAR-2009-0491. Washington, DC: Office of Air and Radiation, Office of Air and Radiation: Office of Policy in Washington, DC.

United States Environmental Protection Agency. 2019a. "USEPA AQS Data Mart." Data retrieved from: https://aqs.epa.gov/aqsweb/airdata/download_ files.html.

United States Environmental Protection Agency. 2019b. "USEPA Mortality Risk." Available at: https://www.epa.gov/environmental-economics/ mortality-risk-valuation.

United States Environmental Protection Agency. 2019c. "USEPA NonAttainment Data." Data retrieved from: https://www.epa.gov/green-book.

Viscusi, W Kip, and Joseph E Aldy. 2003. "The value of a statistical life: a critical review of market estimates throughout the world." Journal of risk and uncertainty, 27(1): 5-76. 
Volcovici, Valerie. 2019. "EPA Fines for Polluters at Lowest Level in Two Decades, Data Shows." Reuters. Available at: https://tinyurl.com/ya8hv6eb.

Zhang, Hongliang, Jianlin Hu, Michael Kleeman, and Qi Ying. 2014. "Source apportionment of sulfate and nitrate particulate matter in the Eastern United States and effectiveness of emission control programs." Science of the Total Environment, 490: $171-181$. 


\section{Figures and Tables}

Figure 1: Map Showing Counties with at Least One Monitor

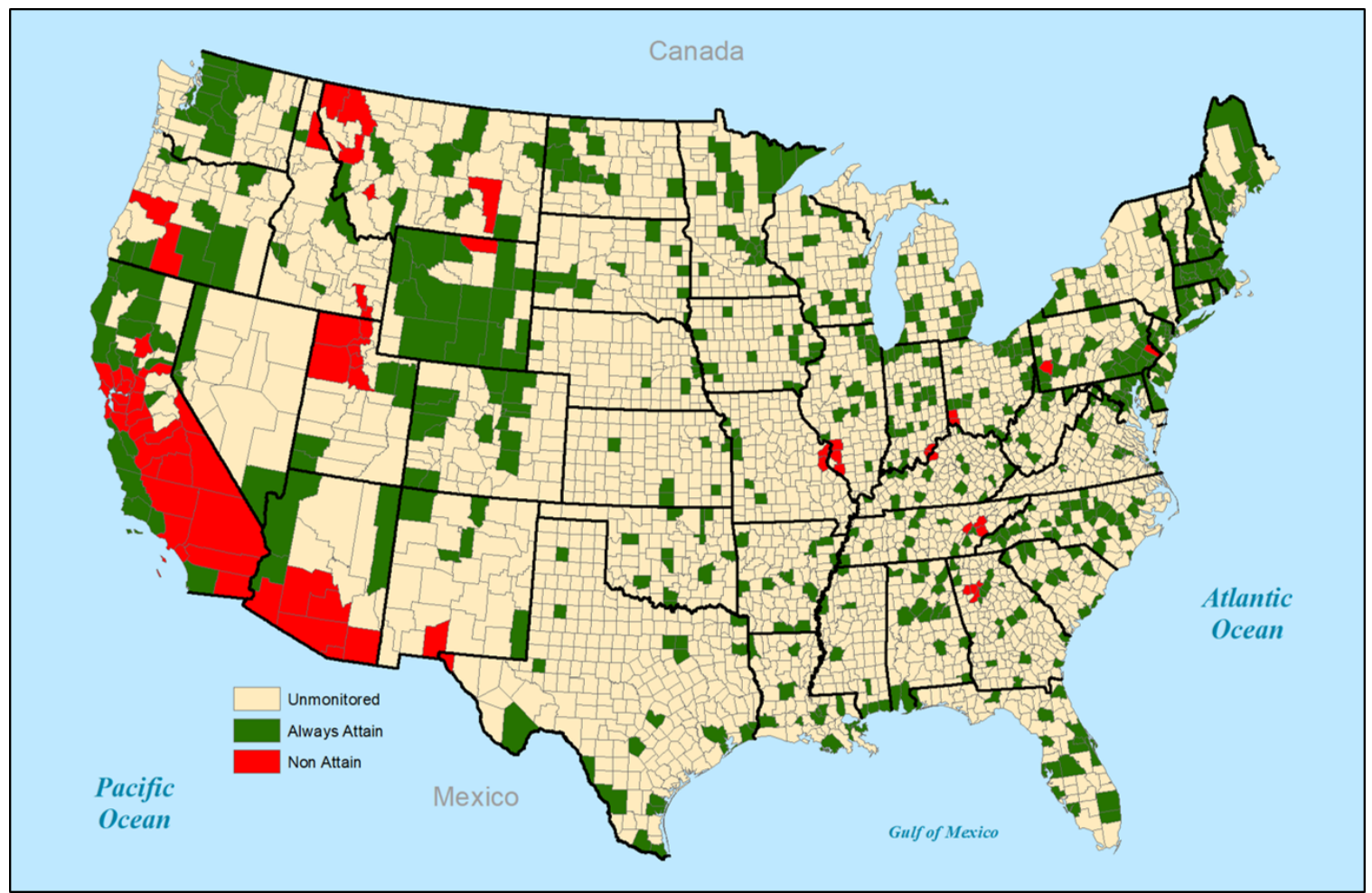

Notes: The map shows counties that had at least one $\mathrm{PM}_{2.5}$ monitor during 2009-2018. 
Figure 2: $\mathrm{PM}_{2.5}$ Over Time

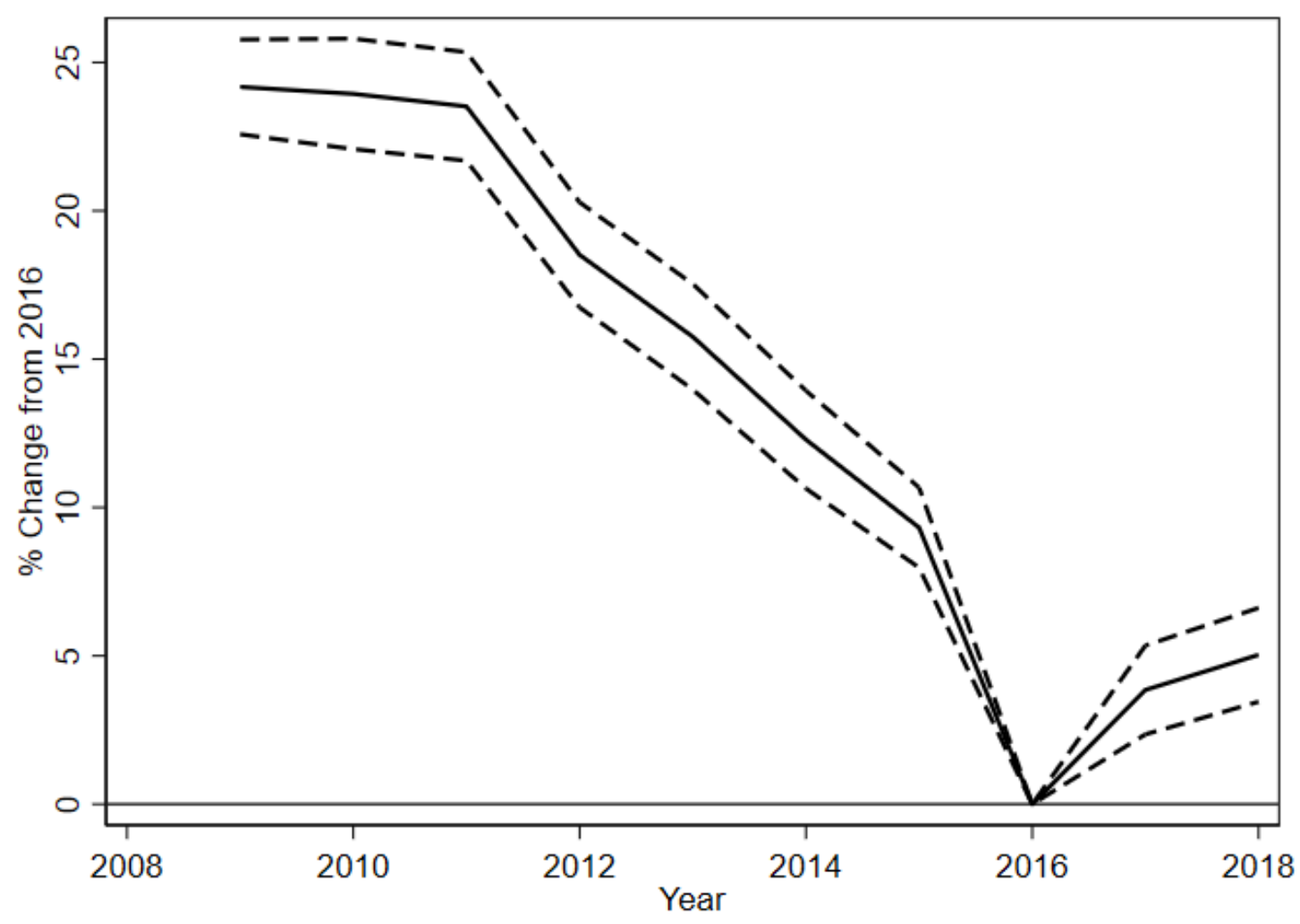

Notes: The figure plots the year fixed effects from the estimation of equation 1 . The 95-percent confidence intervals are shown. The regression results are reported in Table 1. The national average $\mathrm{PM}_{2.5}$ level in 2016 was $7.51 \mu \mathrm{g} / \mathrm{m}^{3}$. 
Figure 3: $\mathrm{PM}_{2.5}$ by Census Region

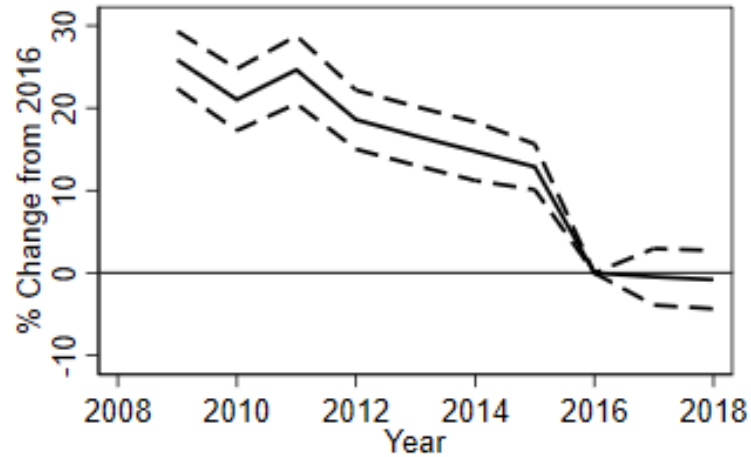

(a) Northeast

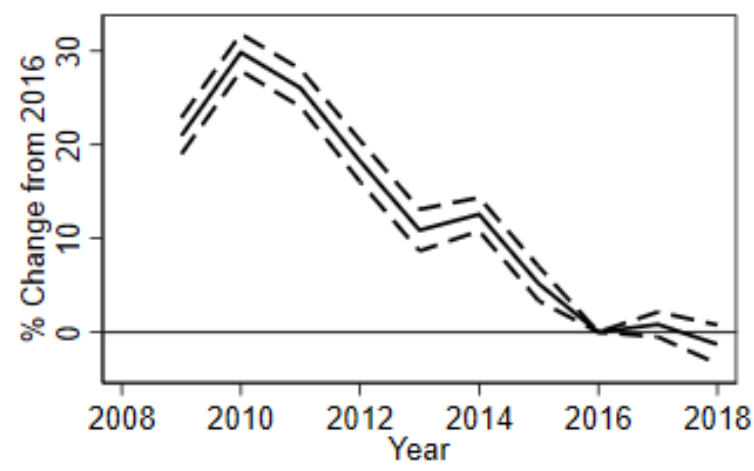

(c) South

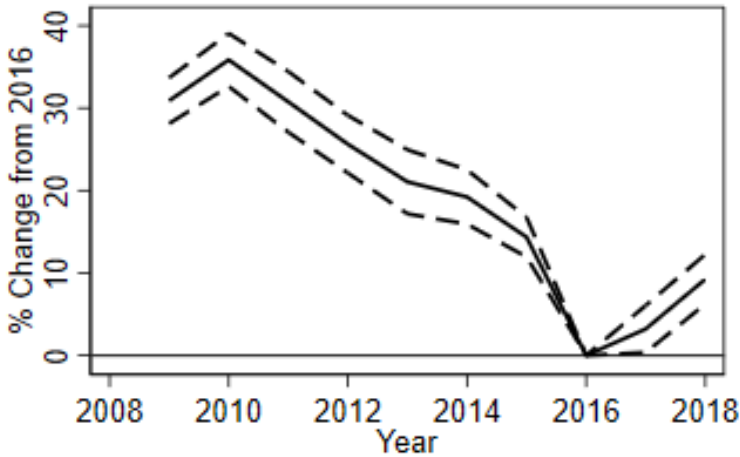

(b) Midwest

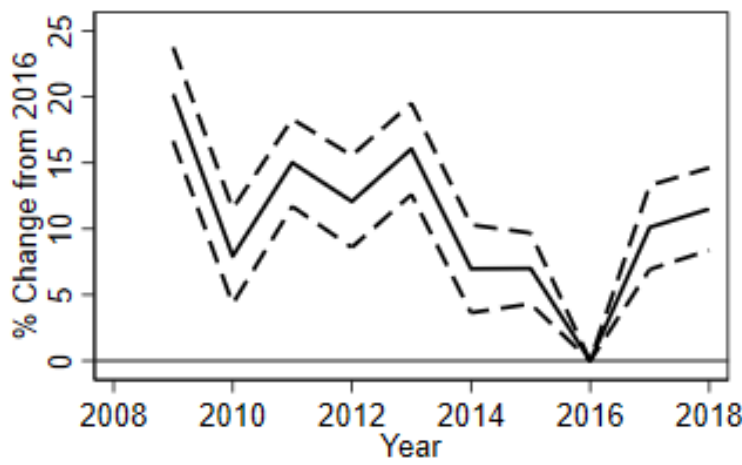

(d) West

Notes: The figures plots the year fixed effects from the estimation of separate equations for each region. The 95-percent confidence intervals are shown for each plot. The top left plot is the Northeast. The top right plot is the Midwest. The bottom left plot is the South. The bottom right plot is the West. The regression results are reported in Table 1 . Note the vertical scales differ across the four plots. The average $\mathrm{PM}_{2.5}$ levels in 2016 for the Northeast, Midwest, South, and West were: 7.50, 7.19, 8.09, and $7.34 \mu \mathrm{g} / \mathrm{m}^{3}$. 
Figure 4: $\mathrm{PM}_{2.5}$ By Attainment Status

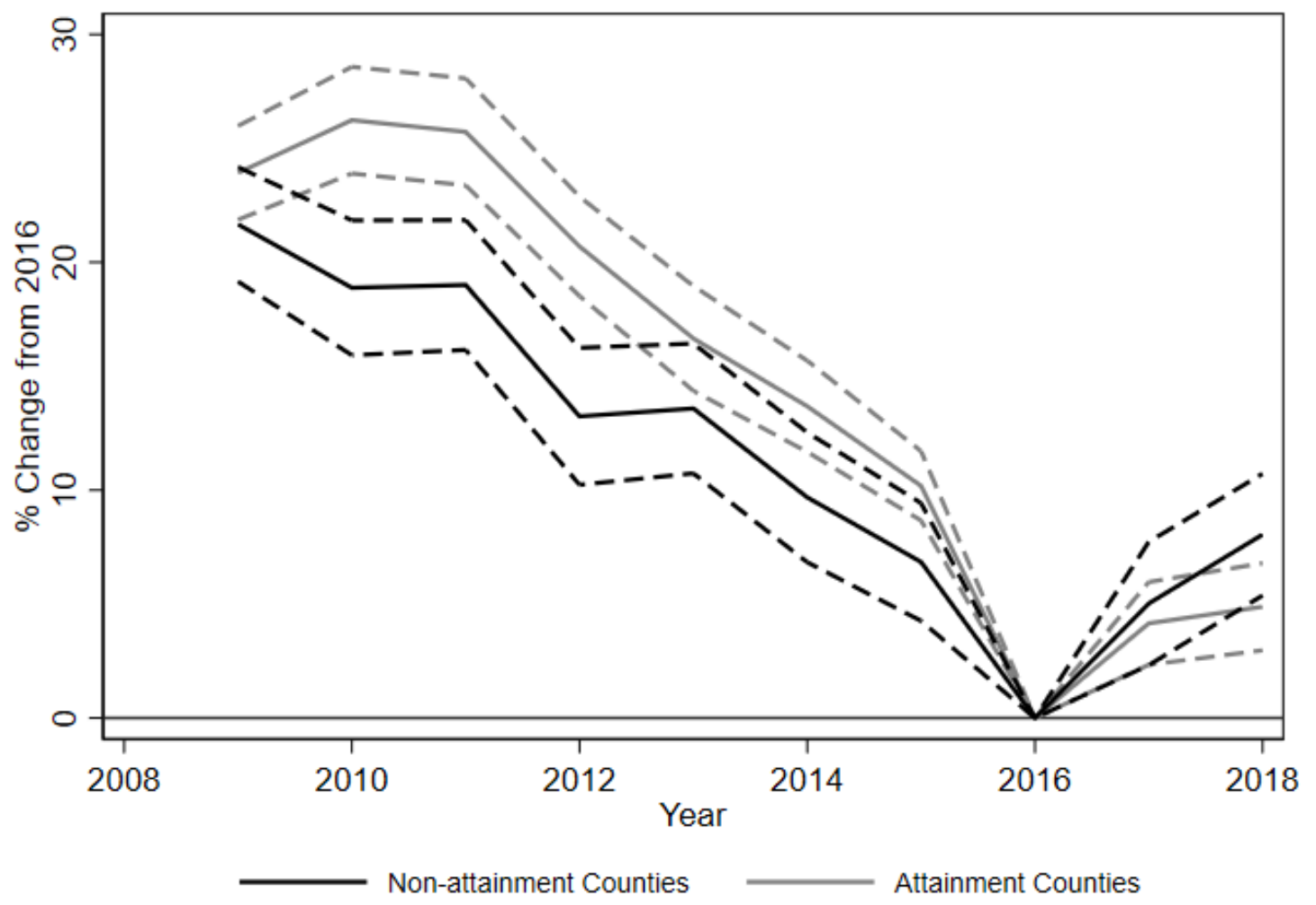

Notes: The black line plots year fixed effects for nonattainment counties and the light gray line plots the year fixed effects for attainment counties. The 95-percent confidence intervals are shown. The regression results are reported in Table 2 . The average $\mathrm{PM}_{2.5}$ levels in 2016 for nonattainment and attainment counties were: 8.73 and $7.05 \mu \mathrm{g} / \mathrm{m}^{3}$. 
Figure 5: $\mathrm{PM}_{2.5}$, Sulfate, Nitrate, and Elemental Carbon

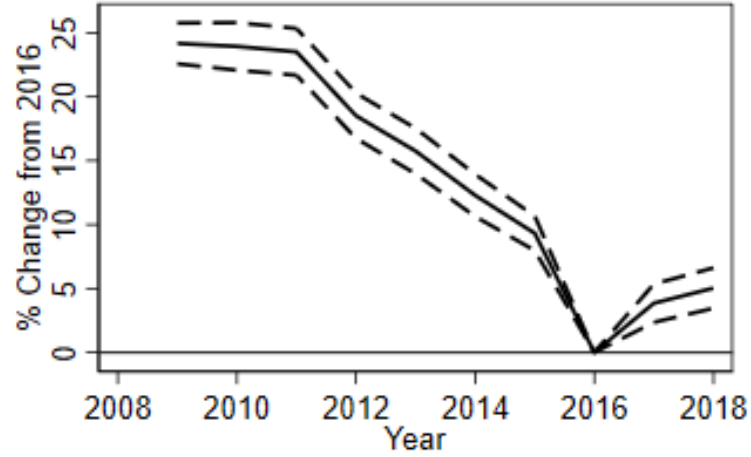

(a) PM2.5

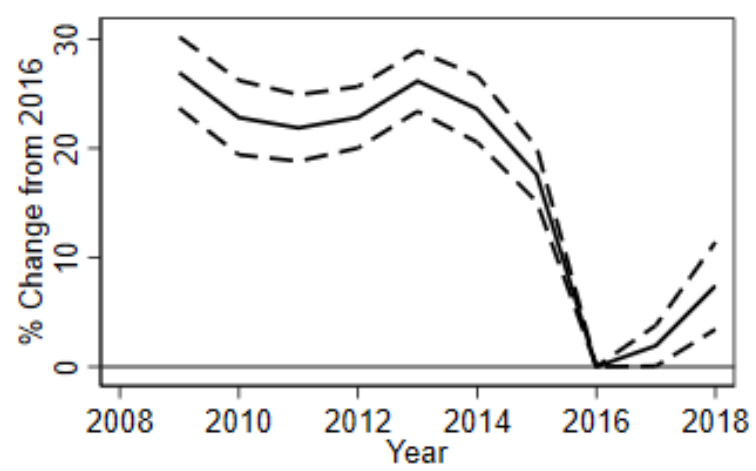

(c) Nitrate

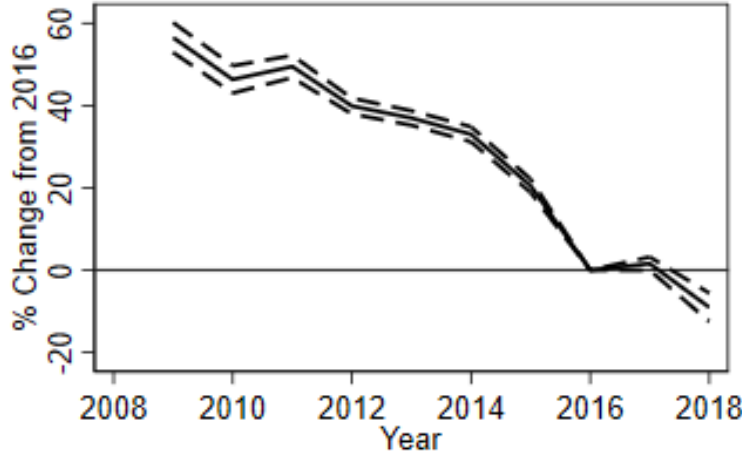

(b) Sulfate

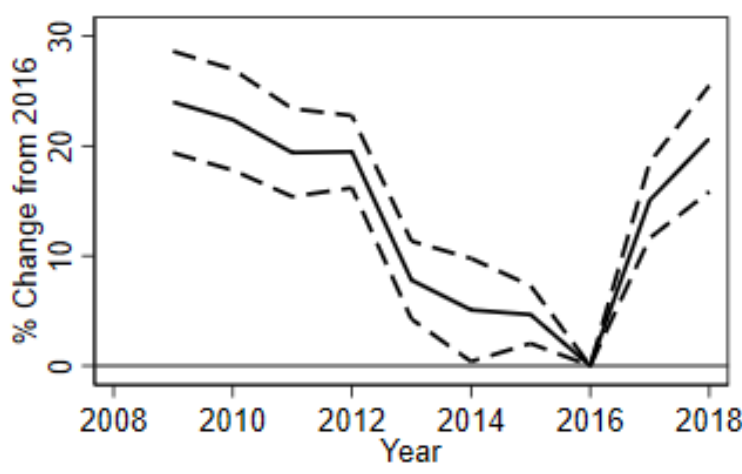

(d) Elemental Carbon

Notes: The top left plot is $\mathrm{PM}_{2.5}$ for reference. The top right plot is sulfate. The bottom left plot is nitrate. The bottom right plot is elemental carbon. The 95-percent confidence intervals are shown for each plot. The regression results are reported in Table 3 . Note the vertical scales differ across the four plots. The average levels in 2016 for $\mathrm{PM}_{2.5}$, sulfate, nitrate, and elemental carbon were: $7.51,0.76,0.55$, and $0.33 \mu \mathrm{g} / \mathrm{m}^{3}$. 
Figure 6: Clean Air Act 113d Enforcement Actions

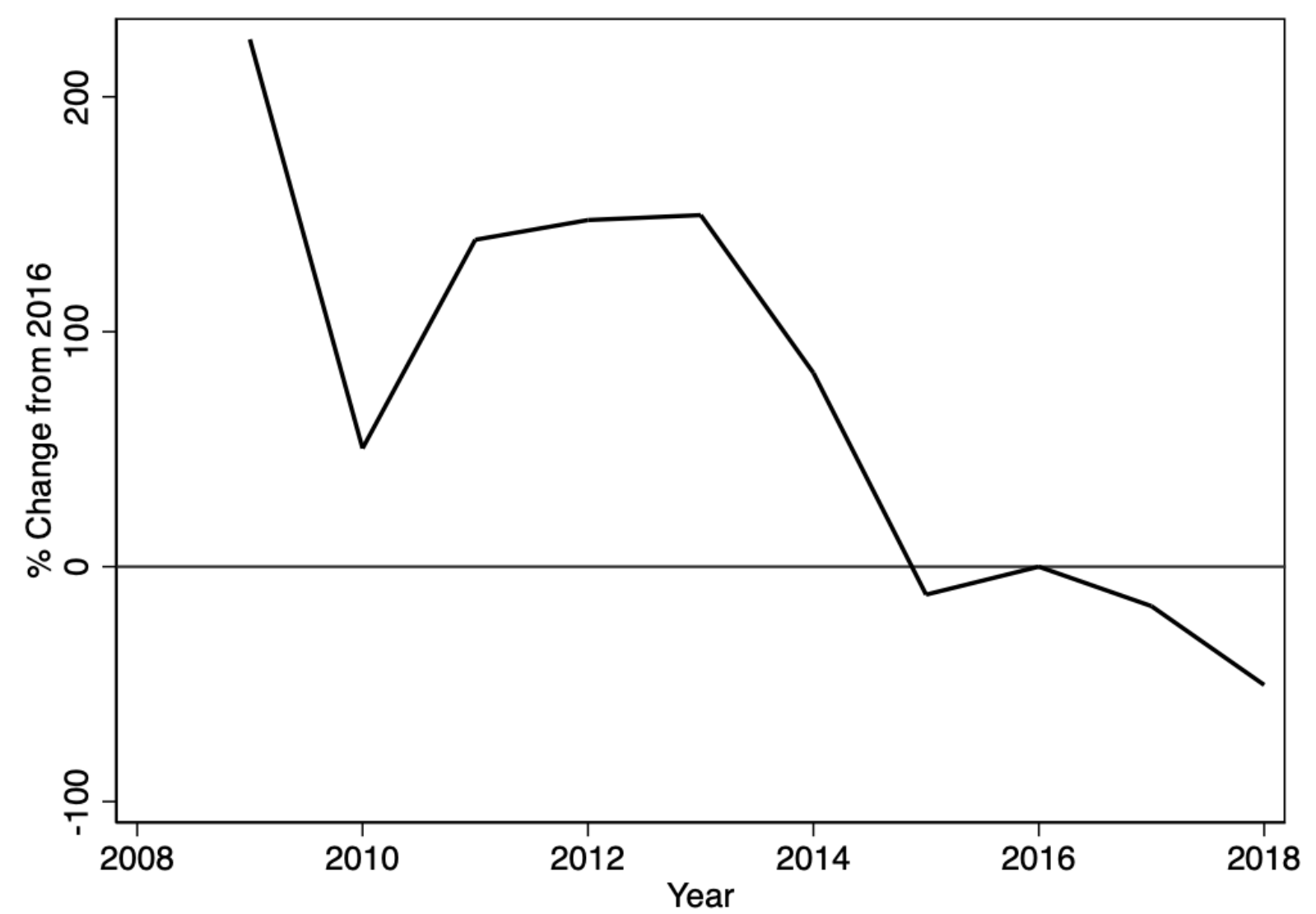

Notes: The figure plots percentage changes in Clean Air Act 113d Enforcement Actions relative to 2016. In 2016, there were 177 actions. 
Figure 7: Clean Air Act 113d Actions by County Attainment Status

Panel A: Counties in Attainment

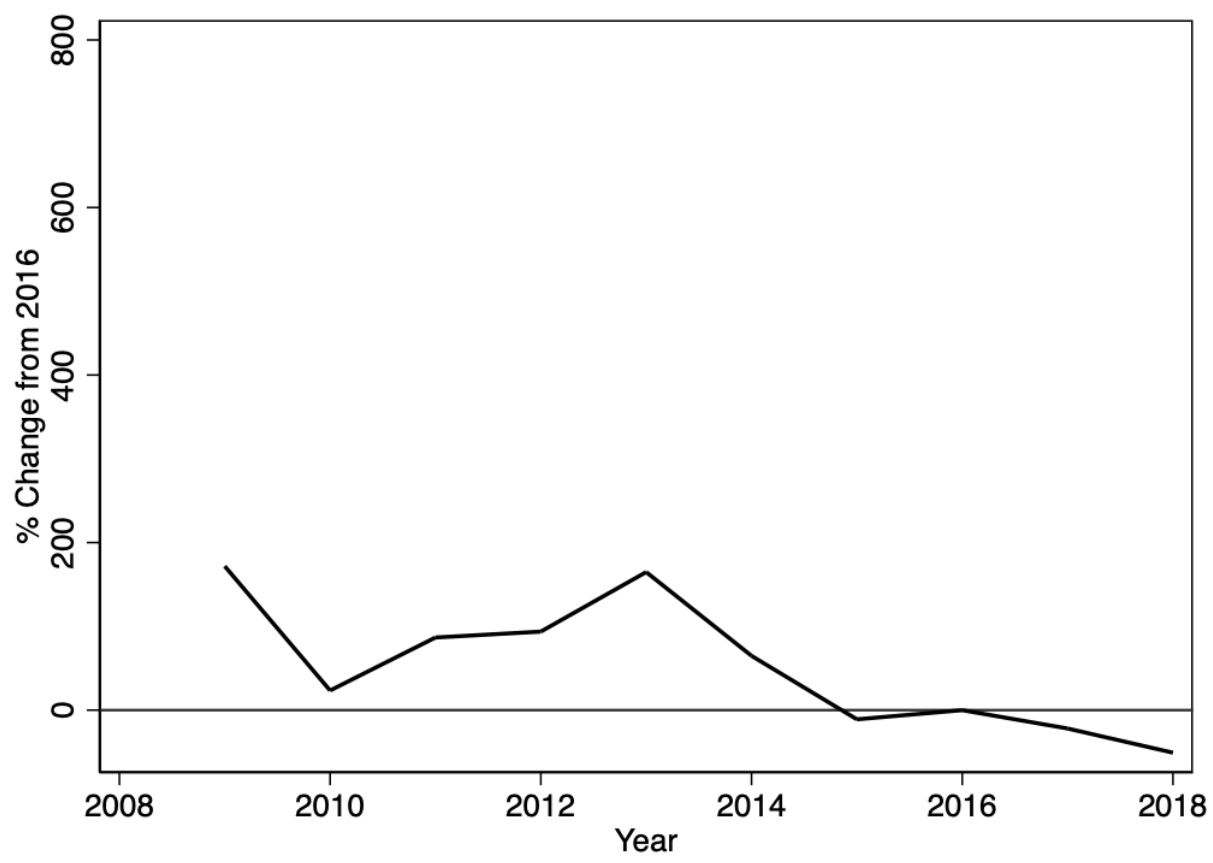

Panel B: Counties in NonAttainment

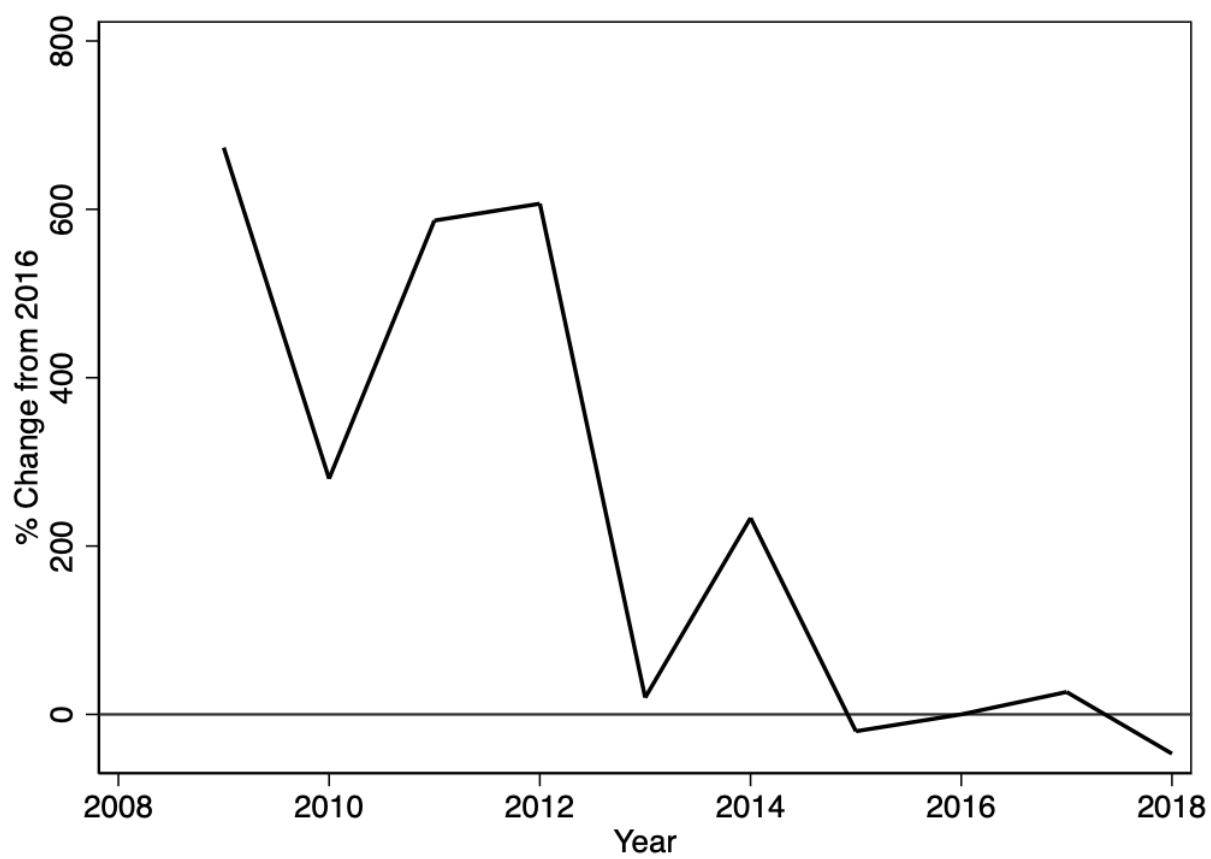

Notes: The figure plots percentage changes in Clean Air Act 113d Enforcement Actions relative to 2016. The top panel is for counties in attainment. The bottom panel is for counties in nonattainment. In 2016, there were 164 actions in attainment counties and 13 actions in nonattainment counties. 
Table 1: $\mathrm{PM}_{2.5}$ Nationally and by Census Region

\begin{tabular}{|c|c|c|c|c|c|}
\hline & $\begin{array}{c}(1) \\
\text { National }\end{array}$ & $\begin{array}{c}(2) \\
\text { Northeast }\end{array}$ & $\begin{array}{c}(3) \\
\text { Midwest }\end{array}$ & $\begin{array}{c}(4) \\
\text { South }\end{array}$ & $\begin{array}{c}(5) \\
\text { West }\end{array}$ \\
\hline year $=2009$ & $\begin{array}{c}0.242^{* * *} \\
(0.008)\end{array}$ & $\begin{array}{c}0.258^{* * *} \\
(0.020)\end{array}$ & $\begin{array}{c}0.309^{* * *} \\
(0.016)\end{array}$ & $\begin{array}{c}0.209^{* * *} \\
(0.011)\end{array}$ & $\begin{array}{c}0.202^{* * *} \\
(0.019)\end{array}$ \\
\hline year $=2010$ & $\begin{array}{c}0.242^{* * *} \\
(0.011)\end{array}$ & $\begin{array}{c}0.210^{* * *} \\
(0.020)\end{array}$ & $\begin{array}{c}0.359^{* * *} \\
(0.019)\end{array}$ & $\begin{array}{c}0.298^{* * *} \\
(0.011)\end{array}$ & $\begin{array}{c}0.079^{* * *} \\
(0.019)\end{array}$ \\
\hline year $=2011$ & $\begin{array}{c}0.238^{* * *} \\
(0.010)\end{array}$ & $\begin{array}{c}0.246^{* * *} \\
(0.022)\end{array}$ & $\begin{array}{c}0.308^{* * *} \\
(0.021)\end{array}$ & $\begin{array}{c}0.261^{* * *} \\
(0.012)\end{array}$ & $\begin{array}{c}0.150^{* * *} \\
(0.019)\end{array}$ \\
\hline year $=2012$ & $\begin{array}{c}0.183^{* * *} \\
(0.010)\end{array}$ & $\begin{array}{c}0.186^{* * *} \\
(0.019)\end{array}$ & $\begin{array}{c}0.256^{* * *} \\
(0.019)\end{array}$ & $\begin{array}{c}0.182^{* * *} \\
(0.013)\end{array}$ & $\begin{array}{c}0.121^{* * *} \\
(0.019)\end{array}$ \\
\hline year $=2013$ & $\begin{array}{c}0.161^{* * *} \\
(0.010)\end{array}$ & $\begin{array}{c}0.166^{* * *} \\
(0.020)\end{array}$ & $\begin{array}{c}0.211^{* * *} \\
(0.020)\end{array}$ & $\begin{array}{c}0.109^{* * *} \\
(0.013)\end{array}$ & $\begin{array}{c}0.161^{* * *} \\
(0.020)\end{array}$ \\
\hline year $=2014$ & $\begin{array}{c}0.128^{* * *} \\
(0.008)\end{array}$ & $\begin{array}{c}0.148^{* * *} \\
(0.020)\end{array}$ & $\begin{array}{c}0.192^{* * *} \\
(0.017)\end{array}$ & $\begin{array}{c}0.126^{* * *} \\
(0.011)\end{array}$ & $\begin{array}{c}0.070^{* * *} \\
(0.017)\end{array}$ \\
\hline year $=2015$ & $\begin{array}{c}0.094^{* * *} \\
(0.007)\end{array}$ & $\begin{array}{c}0.129^{* * *} \\
(0.015)\end{array}$ & $\begin{array}{c}0.143^{* * *} \\
(0.012)\end{array}$ & $\begin{array}{c}0.052^{* * *} \\
(0.010)\end{array}$ & $\begin{array}{c}0.070^{* * *} \\
(0.016)\end{array}$ \\
\hline year $=2016$ & $\begin{array}{c}0.000 \\
(.)\end{array}$ & $\begin{array}{c}0.000 \\
(.)\end{array}$ & $\begin{array}{c}0.000 \\
(.)\end{array}$ & $\begin{array}{c}0.000 \\
(.)\end{array}$ & $\begin{array}{c}0.000 \\
(.)\end{array}$ \\
\hline year $=2017$ & $\begin{array}{c}0.042^{* * *} \\
(0.008)\end{array}$ & $\begin{array}{l}-0.005 \\
(0.018)\end{array}$ & $\begin{array}{l}0.032^{* *} \\
(0.016)\end{array}$ & $\begin{array}{c}0.008 \\
(0.007)\end{array}$ & $\begin{array}{c}0.101^{* * *} \\
(0.016)\end{array}$ \\
\hline year $=2018$ & $\begin{array}{c}0.055^{* * *} \\
(0.008)\end{array}$ & $\begin{array}{l}-0.008 \\
(0.020)\end{array}$ & $\begin{array}{c}0.093^{* * *} \\
(0.015)\end{array}$ & $\begin{array}{l}-0.013 \\
(0.011)\end{array}$ & $\begin{array}{c}0.115^{* * *} \\
(0.016)\end{array}$ \\
\hline $\begin{array}{l}\text { Observations } \\
\text { Adiusted } R^{2}\end{array}$ & $\begin{array}{c}1831810 \\
0.045\end{array}$ & $\begin{array}{c}310065 \\
0.075\end{array}$ & $\begin{array}{c}457436 \\
0.075\end{array}$ & $\begin{array}{c}485840 \\
0.069\end{array}$ & $\begin{array}{c}578469 \\
0.055\end{array}$ \\
\hline
\end{tabular}

Notes: The dependent variable is the natural log of $\mathrm{PM}_{2.5}$. The table reports the year fixed effects from the estimation of equation 1. Monitor, month, and day of month fixed effects are estimated but not reported. Standard errors are clustered at the monitor level. The national average $\mathrm{PM}_{2.5}$ level in 2016 was $7.51 \mu \mathrm{g} / \mathrm{m}^{3}$. The average $\mathrm{PM}_{2.5}$ levels in 2016 for the Northeast, Midwest, South, and West were: $7.50,7.19,8.09$, and $7.34 \mu \mathrm{g} / \mathrm{m}^{3}$. 
Table 2: $\mathrm{PM}_{2.5}$ by County Attainment Status

\begin{tabular}{|c|c|c|c|c|}
\hline & $\begin{array}{l}(1) \\
\text { NA }\end{array}$ & $\begin{array}{l}(2) \\
\text { Att }\end{array}$ & $\begin{array}{c}(3) \\
\text { NA Any }\end{array}$ & $\begin{array}{c}(4) \\
\text { Att All }\end{array}$ \\
\hline year $=2009$ & $\begin{array}{c}0.217^{* * *} \\
(0.014)\end{array}$ & $\begin{array}{c}0.239^{* * *} \\
(0.011)\end{array}$ & $\begin{array}{c}0.218^{* * *} \\
(0.011)\end{array}$ & $\begin{array}{c}0.255^{* * *} \\
(0.013)\end{array}$ \\
\hline year $=2010$ & $\begin{array}{c}0.189^{* * *} \\
(0.020)\end{array}$ & $\begin{array}{c}0.262^{* * *} \\
(0.013)\end{array}$ & $\begin{array}{c}0.190^{* * *} \\
(0.016)\end{array}$ & $\begin{array}{c}0.288^{* * *} \\
(0.014)\end{array}$ \\
\hline year $=2011$ & $\begin{array}{c}0.190^{* * *} \\
(0.019)\end{array}$ & $\begin{array}{c}0.257^{* * *} \\
(0.012)\end{array}$ & $\begin{array}{c}0.193^{* * *} \\
(0.014)\end{array}$ & $\begin{array}{c}0.277^{* * *} \\
(0.014)\end{array}$ \\
\hline year $=2012$ & $\begin{array}{c}0.132^{* * *} \\
(0.019)\end{array}$ & $\begin{array}{c}0.207^{* * *} \\
(0.012)\end{array}$ & $\begin{array}{c}0.138^{* * *} \\
(0.013)\end{array}$ & $\begin{array}{c}0.222^{* * *} \\
(0.013)\end{array}$ \\
\hline year $=2013$ & $\begin{array}{c}0.136^{* * *} \\
(0.018)\end{array}$ & $\begin{array}{c}0.167^{* * *} \\
(0.012)\end{array}$ & $\begin{array}{c}0.131^{* * *} \\
(0.013)\end{array}$ & $\begin{array}{c}0.183^{* * *} \\
(0.015)\end{array}$ \\
\hline year $=2014$ & $\begin{array}{c}0.097^{* * *} \\
(0.017)\end{array}$ & $\begin{array}{c}0.137^{* * *} \\
(0.010)\end{array}$ & $\begin{array}{c}0.102^{* * *} \\
(0.012)\end{array}$ & $\begin{array}{c}0.146^{* * *} \\
(0.012)\end{array}$ \\
\hline year $=2015$ & $\begin{array}{c}0.068^{* * *} \\
(0.015)\end{array}$ & $\begin{array}{c}0.102^{* * *} \\
(0.008)\end{array}$ & $\begin{array}{c}0.071^{* * *} \\
(0.011)\end{array}$ & $\begin{array}{c}0.108^{* * *} \\
(0.010)\end{array}$ \\
\hline year $=2016$ & $\begin{array}{c}0.000 \\
(.)\end{array}$ & $\begin{array}{c}0.000 \\
(.)\end{array}$ & $\begin{array}{c}0.000 \\
(.)\end{array}$ & $\begin{array}{c}0.000 \\
(.)\end{array}$ \\
\hline year $=2017$ & $\begin{array}{c}0.050^{* * *} \\
(0.017)\end{array}$ & $\begin{array}{c}0.042^{* * *} \\
(0.009)\end{array}$ & $\begin{array}{l}0.026^{* *} \\
(0.012)\end{array}$ & $\begin{array}{c}0.060^{* * *} \\
(0.010)\end{array}$ \\
\hline year $=2018$ & $\begin{array}{c}0.081^{* * *} \\
(0.017)\end{array}$ & $\begin{array}{c}0.049^{* * *} \\
(0.009)\end{array}$ & $\begin{array}{c}0.046^{* * *} \\
(0.012)\end{array}$ & $\begin{array}{c}0.062^{* * *} \\
(0.011)\end{array}$ \\
\hline $\begin{array}{l}\text { Observations } \\
\text { Adjusted } R^{2}\end{array}$ & $\begin{array}{c}616127 \\
0.056\end{array}$ & $\begin{array}{c}1215683 \\
0.041\end{array}$ & $\begin{array}{c}906758 \\
0.050\end{array}$ & $\begin{array}{c}925052 \\
0.042\end{array}$ \\
\hline
\end{tabular}

Notes: Columns 1 and 2 define county nonattainment status as nonattainment for nitrogen dioxide, sulfur dioxide, and $\mathrm{PM}_{2.5}$. Columns 3 and 4 define county nonattainment status as nonattainment for any criteria pollutant. The dependent variable is the natural $\log$ of $\mathrm{PM}_{2.5}$. The table reports the year fixed effects from the estimation of equation 1. Monitor, month, and day of month fixed effects are estimated but not reported. Standard errors are clustered at the monitor level. The average $\mathrm{PM}_{2.5}$ levels in 2016 for nonattainment and attainment counties were: 8.73 and $7.05 \mu \mathrm{g} / \mathrm{m}^{3}$. 
Table 3: Sulfate, Nitrate, and Elemental Carbon

\begin{tabular}{|c|c|c|c|}
\hline & $\begin{array}{c}(1) \\
\text { Sulfate }\end{array}$ & $\begin{array}{c}(2) \\
\text { Nitrate }\end{array}$ & $\begin{array}{c}(3) \\
\text { Elemental }\end{array}$ \\
\hline year $=2009$ & $\begin{array}{c}0.565^{* * *} \\
(0.019)\end{array}$ & $\begin{array}{c}0.269^{* * *} \\
(0.017)\end{array}$ & $\begin{array}{c}0.240^{* * *} \\
(0.024)\end{array}$ \\
\hline year $=2010$ & $\begin{array}{c}0.463^{* * *} \\
(0.017)\end{array}$ & $\begin{array}{c}0.228^{* * *} \\
(0.017)\end{array}$ & $\begin{array}{c}0.224^{* * *} \\
(0.023)\end{array}$ \\
\hline year $=2011$ & $\begin{array}{c}0.495^{* * *} \\
(0.014)\end{array}$ & $\begin{array}{c}0.219^{* * *} \\
(0.016)\end{array}$ & $\begin{array}{c}0.194^{* * *} \\
(0.020)\end{array}$ \\
\hline year $=2012$ & $\begin{array}{c}0.399^{* * *} \\
(0.010)\end{array}$ & $\begin{array}{c}0.228^{* * *} \\
(0.014)\end{array}$ & $\begin{array}{c}0.195^{* * *} \\
(0.017)\end{array}$ \\
\hline year $=2013$ & $\begin{array}{c}0.370^{* * *} \\
(0.009)\end{array}$ & $\begin{array}{c}0.262^{* * *} \\
(0.014)\end{array}$ & $\begin{array}{c}0.078^{* * *} \\
(0.018)\end{array}$ \\
\hline year $=2014$ & $\begin{array}{c}0.330^{* * *} \\
(0.009)\end{array}$ & $\begin{array}{c}0.236^{* * *} \\
(0.016)\end{array}$ & $\begin{array}{l}0.051^{* *} \\
(0.024)\end{array}$ \\
\hline year $=2015$ & $\begin{array}{c}0.205^{* * *} \\
(0.008)\end{array}$ & $\begin{array}{c}0.176^{* * *} \\
(0.013)\end{array}$ & $\begin{array}{c}0.047^{* * *} \\
(0.013)\end{array}$ \\
\hline year $=2016$ & $\begin{array}{c}0.000 \\
(.)\end{array}$ & $\begin{array}{c}0.000 \\
(.)\end{array}$ & $\begin{array}{c}0.000 \\
(.)\end{array}$ \\
\hline year $=2017$ & $\begin{array}{l}0.016^{*} \\
(0.008)\end{array}$ & $\begin{array}{l}0.019^{* *} \\
(0.009)\end{array}$ & $\begin{array}{c}0.151^{* * *} \\
(0.018)\end{array}$ \\
\hline year $=2018$ & $\begin{array}{c}-0.090^{* * *} \\
(0.018)\end{array}$ & $\begin{array}{c}0.074^{* * *} \\
(0.020)\end{array}$ & $\begin{array}{c}0.207^{* * *} \\
(0.025)\end{array}$ \\
\hline $\begin{array}{l}\text { Observations } \\
\text { Adjusted } R^{2}\end{array}$ & $\begin{array}{c}307089 \\
0.151\end{array}$ & $\begin{array}{c}298278 \\
0.138\end{array}$ & $\begin{array}{c}296833 \\
0.039\end{array}$ \\
\hline
\end{tabular}

Notes: The dependent variable is the natural log of the species. The table reports the year fixed effects from the estimation of equation 1. Monitor, month, and day of month fixed effects are estimated but not reported. Standard errors are clustered at the monitor level. The average levels in 2016 for sulfate, nitrate, and elemental carbon were: $0.76,0.55$, and $0.33 \mu \mathrm{g} / \mathrm{m}^{3}$. 
Table 4: $\mathrm{PM}_{2.5}$ in the West, Midwest, and California, without June-September or November

\begin{tabular}{|c|c|c|c|c|c|}
\hline & $\begin{array}{c}(1) \\
\text { West }\end{array}$ & $\begin{array}{c}(2) \\
\text { Midwest }\end{array}$ & $\begin{array}{c}(3) \\
\text { CAall }\end{array}$ & $\begin{array}{c}(4) \\
\text { CAnoJ-S }\end{array}$ & $\begin{array}{c}(5) \\
\text { CAnoNov }\end{array}$ \\
\hline year $=2009$ & $\begin{array}{c}0.235^{* * *} \\
(0.020)\end{array}$ & $\begin{array}{c}0.290^{* * *} \\
(0.016)\end{array}$ & $\begin{array}{c}0.219^{* * *} \\
(0.024)\end{array}$ & $\begin{array}{c}0.276^{* * *} \\
(0.027)\end{array}$ & $\begin{array}{c}0.210^{* * *} \\
(0.025)\end{array}$ \\
\hline year $=2010$ & $\begin{array}{c}0.123^{* * *} \\
(0.021)\end{array}$ & $\begin{array}{c}0.363^{* * *} \\
(0.022)\end{array}$ & $\begin{array}{l}0.065^{* *} \\
(0.025)\end{array}$ & $\begin{array}{c}0.093^{* * *} \\
(0.030)\end{array}$ & $\begin{array}{c}0.070^{* * *} \\
(0.024)\end{array}$ \\
\hline year $=2011$ & $\begin{array}{c}0.175^{* * *} \\
(0.020)\end{array}$ & $\begin{array}{c}0.262^{* * *} \\
(0.023)\end{array}$ & $\begin{array}{c}0.145^{* * *} \\
(0.026)\end{array}$ & $\begin{array}{c}0.201^{* * *} \\
(0.034)\end{array}$ & $\begin{array}{c}0.147^{* * *} \\
(0.027)\end{array}$ \\
\hline year $=2012$ & $\begin{array}{c}0.094^{* * *} \\
(0.016)\end{array}$ & $\begin{array}{c}0.213^{* * *} \\
(0.021)\end{array}$ & $\begin{array}{l}0.040^{* *} \\
(0.020)\end{array}$ & $\begin{array}{c}0.077^{* * *} \\
(0.022)\end{array}$ & $\begin{array}{c}0.040^{*} \\
(0.021)\end{array}$ \\
\hline year $=2013$ & $\begin{array}{c}0.231^{* * *} \\
(0.024)\end{array}$ & $\begin{array}{c}0.139^{* * *} \\
(0.021)\end{array}$ & $\begin{array}{c}0.132^{* * *} \\
(0.030)\end{array}$ & $\begin{array}{c}0.251^{* * *} \\
(0.042)\end{array}$ & $\begin{array}{c}0.126^{* * *} \\
(0.029)\end{array}$ \\
\hline year $=2014$ & $\begin{array}{c}0.096^{* * *} \\
(0.017)\end{array}$ & $\begin{array}{c}0.153^{* * *} \\
(0.017)\end{array}$ & $\begin{array}{c}0.053^{* * *} \\
(0.019)\end{array}$ & $\begin{array}{c}0.114^{* * *} \\
(0.021)\end{array}$ & $\begin{array}{l}0.050^{* *} \\
(0.020)\end{array}$ \\
\hline year $=2015$ & $\begin{array}{c}0.089^{* * *} \\
(0.016)\end{array}$ & $\begin{array}{c}0.076^{* * *} \\
(0.011)\end{array}$ & $\begin{array}{l}0.048^{*} \\
(0.024)\end{array}$ & $\begin{array}{c}0.116^{* * *} \\
(0.028)\end{array}$ & $\begin{array}{l}0.058^{* *} \\
(0.024)\end{array}$ \\
\hline year $=2016$ & $\begin{array}{c}0.000 \\
(.)\end{array}$ & $\begin{array}{c}0.000 \\
(.)\end{array}$ & $\begin{array}{c}0.000 \\
(.)\end{array}$ & $\begin{array}{c}0.000 \\
(.)\end{array}$ & $\begin{array}{c}0.000 \\
(.)\end{array}$ \\
\hline year $=2017$ & $\begin{array}{c}0.052^{* * *} \\
(0.014)\end{array}$ & $\begin{array}{l}-0.027^{*} \\
(0.014)\end{array}$ & $\begin{array}{c}0.074^{* * *} \\
(0.022)\end{array}$ & $\begin{array}{c}0.072^{* * *} \\
(0.020)\end{array}$ & $\begin{array}{c}0.086^{* * *} \\
(0.024)\end{array}$ \\
\hline year $=2018$ & $\begin{array}{c}0.049^{* * *} \\
(0.017)\end{array}$ & $\begin{array}{c}0.042^{* * *} \\
(0.016)\end{array}$ & $\begin{array}{c}0.154^{* * *} \\
(0.027)\end{array}$ & $\begin{array}{c}0.125^{* * *} \\
(0.028)\end{array}$ & $\begin{array}{c}0.126^{* * *} \\
(0.025)\end{array}$ \\
\hline $\begin{array}{l}\text { Observations } \\
\text { Adjusted } R^{2}\end{array}$ & $\begin{array}{c}384646 \\
0.067\end{array}$ & $\begin{array}{c}305095 \\
0.080\end{array}$ & $\begin{array}{c}256408 \\
0.052\end{array}$ & $\begin{array}{c}171385 \\
0.067\end{array}$ & $\begin{array}{c}234682 \\
0.053\end{array}$ \\
\hline
\end{tabular}

Notes: Column 1: West without June - Sept. Column 2: Midwest without June - Sept. Column 3: CA all months. Column 4: CA without June-Sept. Column 5: CA without Nov. The dependent variable is the natural $\log$ of $\mathrm{PM}_{2.5}$. The table reports the year fixed effects from the estimation of equation 1. Monitor, month, and day of month fixed effects are estimated but not reported. Standard errors are clustered at the monitor level. 
Table 5: Deaths and Damages from $\mathrm{PM}_{2.5}$

\begin{tabular}{lccc}
\hline \hline Sample & Years & Deaths & Damages (billions) \\
\hline US & $2017-2016$ & 4,881 & $\$ 45.1$ \\
US & $2018-2016$ & 9,666 & $\$ 89.4$ \\
& & & $\$ 25.4$ \\
US, dropping June-Sept & $2017-2016$ & 2,747 & $\$ 57.6$ \\
US, dropping June-Sept & $2018-2016$ & 6,228 & $\$ 19.4$ \\
\hline \hline & & & $\$ 38.2$ \\
CA & $2017-2016$ & 2,099 & \\
CA & $2018-2016$ & 4,129 & $\$ 20.4$ \\
CA, dropping June-Sept & $2017-2016$ & 2,201 & $\$ 37.8$ \\
CA, dropping June-Sept & $2018-2016$ & 4,085 & \\
\hline
\end{tabular}

Notes: Deaths and damages are changes in counties with PM2.5 monitors. Deaths are individuals who are 30 or older. Damages are in billions (\$2016) at 2016 income levels. 


\section{A Appendix}

Table A.1: Annual Averages for 2016

\begin{tabular}{lccccc}
\hline \hline & National & Northeast & Midwest & South & West \\
\hline $\mathrm{PM}_{2.5} \mu \mathrm{g} / \mathrm{m}^{3}$ & 7.51 & 7.50 & 7.19 & 8.09 & 7.34 \\
$\mathrm{PM}_{2.5}$ Excluding Fire Season & & & 7.45 & & 7.35 \\
$\mathrm{PM}_{2.5}$ Nonatt. Counties & 8.73 & & & & \\
$\mathrm{PM}_{2.5}$ Attainment Counties & 7.05 & & & \\
$\mathrm{PM}_{2.5}$ Nonatt. Counties Any & 8.50 & & & \\
$\mathrm{PM}_{2.5}$ Attainment Counties Any & 6.70 & & & \\
Sulfates $\mu \mathrm{g} / \mathrm{m}^{3}$ & 0.76 & & & \\
Nitrates $\mu \mathrm{g} / \mathrm{m}^{3}$ & 0.55 & & & \\
Elemental Carbon $\mu \mathrm{g} / m^{3}$ & 0.32 & & & \\
\hline Enf. Actions $113 \mathrm{~d}$ Penalty & 177 & & & \\
Enf. Nonatt. Counties & 13 & & & \\
Enf. Attainment Counties & 164 & & & \\
Enf. Nonatt. Counties Any & 61 & & & \\
Enf. Attainment Counties Any & 116 & & & \\
\hline
\end{tabular}

Notes: Fire season is June to September, four months. The primary definition of nonattainment status is nonattainment for nitrogen dioxide, sulfur dioxide, and $\mathrm{PM}_{2.5}$. Attainment refers to attainment for nitrogen dioxide, sulfur dioxide, and $\mathrm{PM}_{2.5}$. Nonattainment Any is nonattainment for any criteria pollutant. Attainment Any is attainment for all criteria pollutant. Enforcement actions are counts of Clean Air Act section 113d actions that result in a penalty. 
Table A.2: $\mathrm{PM}_{2.5}$ Nationally and by Census Region, Weighted by Population

\begin{tabular}{|c|c|c|c|c|c|}
\hline & $\begin{array}{c}(1) \\
\text { National }\end{array}$ & $\begin{array}{c}(2) \\
\text { Northeast }\end{array}$ & $\begin{array}{c}(3) \\
\text { Midwest }\end{array}$ & $\begin{array}{c}(4) \\
\text { South }\end{array}$ & $\begin{array}{c}(5) \\
\text { West }\end{array}$ \\
\hline year $=2009$ & $\begin{array}{c}0.225^{* * *} \\
(0.014)\end{array}$ & $\begin{array}{c}0.255^{* * *} \\
(0.026)\end{array}$ & $\begin{array}{c}0.237^{* * *} \\
(0.019)\end{array}$ & $\begin{array}{c}0.175^{* * *} \\
(0.016)\end{array}$ & $\begin{array}{c}0.245^{* * *} \\
(0.021)\end{array}$ \\
\hline year $=2010$ & $\begin{array}{c}0.154^{* * *} \\
(0.027)\end{array}$ & $\begin{array}{c}0.206^{* * *} \\
(0.027)\end{array}$ & $\begin{array}{c}0.272^{* * *} \\
(0.029)\end{array}$ & $\begin{array}{c}0.240^{* * *} \\
(0.016)\end{array}$ & $\begin{array}{c}0.044^{* * *} \\
(0.014)\end{array}$ \\
\hline year $=2011$ & $\begin{array}{c}0.174^{* * *} \\
(0.024)\end{array}$ & $\begin{array}{c}0.247^{* * *} \\
(0.025)\end{array}$ & $\begin{array}{c}0.226^{* * *} \\
(0.041)\end{array}$ & $\begin{array}{c}0.214^{* * *} \\
(0.029)\end{array}$ & $\begin{array}{c}0.124^{* * *} \\
(0.031)\end{array}$ \\
\hline year $=2012$ & $\begin{array}{c}0.127^{* * *} \\
(0.023)\end{array}$ & $\begin{array}{c}0.178^{* * *} \\
(0.023)\end{array}$ & $\begin{array}{c}0.182^{* * *} \\
(0.032)\end{array}$ & $\begin{array}{c}0.163^{* * *} \\
(0.021)\end{array}$ & $\begin{array}{l}0.087^{* *} \\
(0.035)\end{array}$ \\
\hline year $=2013$ & $\begin{array}{c}0.112^{* * *} \\
(0.016)\end{array}$ & $\begin{array}{c}0.137^{* * *} \\
(0.024)\end{array}$ & $\begin{array}{c}0.149^{* * *} \\
(0.020)\end{array}$ & $\begin{array}{c}0.087^{* * *} \\
(0.023)\end{array}$ & $\begin{array}{c}0.102^{* * *} \\
(0.026)\end{array}$ \\
\hline year $=2014$ & $\begin{array}{c}0.112^{* * *} \\
(0.012)\end{array}$ & $\begin{array}{c}0.139^{* * *} \\
(0.021)\end{array}$ & $\begin{array}{c}0.174^{* * *} \\
(0.015)\end{array}$ & $\begin{array}{c}0.122^{* * *} \\
(0.013)\end{array}$ & $\begin{array}{c}0.087^{* * *} \\
(0.019)\end{array}$ \\
\hline year $=2015$ & $\begin{array}{c}0.052^{* * *} \\
(0.016)\end{array}$ & $\begin{array}{c}0.102^{* * *} \\
(0.014)\end{array}$ & $\begin{array}{c}0.111^{* * *} \\
(0.008)\end{array}$ & $\begin{array}{c}0.068^{* * *} \\
(0.017)\end{array}$ & $\begin{array}{c}0.016 \\
(0.020)\end{array}$ \\
\hline year $=2016$ & $\begin{array}{c}0.000 \\
(.)\end{array}$ & $\begin{array}{c}0.000 \\
(.)\end{array}$ & $\begin{array}{c}0.000 \\
(.)\end{array}$ & $\begin{array}{c}0.000 \\
(.)\end{array}$ & $\begin{array}{c}0.000 \\
(.)\end{array}$ \\
\hline year $=2017$ & $\begin{array}{l}0.025^{* *} \\
(0.010)\end{array}$ & $\begin{array}{l}-0.026 \\
(0.017)\end{array}$ & $\begin{array}{l}-0.019 \\
(0.014)\end{array}$ & $\begin{array}{c}0.014 \\
(0.014)\end{array}$ & $\begin{array}{c}0.055^{* * *} \\
(0.015)\end{array}$ \\
\hline year $=2018$ & $\begin{array}{c}0.056^{* * *} \\
(0.010)\end{array}$ & $\begin{array}{c}0.004 \\
(0.019)\end{array}$ & $\begin{array}{c}0.058^{* * *} \\
(0.015)\end{array}$ & $\begin{array}{l}-0.002 \\
(0.015)\end{array}$ & $\begin{array}{c}0.091^{* * *} \\
(0.018)\end{array}$ \\
\hline $\begin{array}{l}\text { Observations } \\
\text { Adiusted } R^{2}\end{array}$ & $\begin{array}{c}1831810 \\
0.039\end{array}$ & $\begin{array}{c}310065 \\
0.083\end{array}$ & $\begin{array}{c}457436 \\
0.087\end{array}$ & $\begin{array}{c}485840 \\
0.057\end{array}$ & $\begin{array}{c}578469 \\
0.050\end{array}$ \\
\hline
\end{tabular}

Notes: The dependent variable is the natural $\log$ of $\mathrm{PM}_{2.5}$. The table reports the year fixed effects from the estimation of equation 1. The regressions are weighted by county population in 2016. Monitor, month, and day of month fixed effects are estimated but not reported. Standard errors are clustered at the monitor level. The national average $\mathrm{PM}_{2.5}$ level in 2016 was $7.51 \mu \mathrm{g} / \mathrm{m}^{3}$. The average $\mathrm{PM}_{2.5}$ levels in 2016 for the Northeast, Midwest, South, and West were: 7.50, 7.19, 8.09, and $7.34 \mu \mathrm{g} / \mathrm{m}^{3}$. 
Table A.3: $\mathrm{PM}_{2.5}$ in the West, Midwest, and California, without June-September or November, Weighted by Population

\begin{tabular}{|c|c|c|c|c|c|}
\hline & $\begin{array}{c}(1) \\
\text { West }\end{array}$ & $\begin{array}{c}(2) \\
\text { Midwest }\end{array}$ & $\begin{array}{c}(3) \\
\text { CAall }\end{array}$ & $\begin{array}{c}(4) \\
\text { CAnoJ-S }\end{array}$ & $\begin{array}{c}(5) \\
\text { CAnoNov }\end{array}$ \\
\hline year $=2009$ & $\begin{array}{c}0.263^{* * *} \\
(0.025)\end{array}$ & $\begin{array}{c}0.244^{* * *} \\
(0.015)\end{array}$ & $\begin{array}{c}0.245^{* * *} \\
(0.021)\end{array}$ & $\begin{array}{c}0.280^{* * *} \\
(0.024)\end{array}$ & $\begin{array}{c}0.235^{* * *} \\
(0.021)\end{array}$ \\
\hline year $=2010$ & $\begin{array}{l}0.040^{* *} \\
(0.019)\end{array}$ & $\begin{array}{c}0.276^{* * *} \\
(0.035)\end{array}$ & $\begin{array}{c}0.029^{*} \\
(0.016)\end{array}$ & $\begin{array}{c}0.030 \\
(0.022)\end{array}$ & $\begin{array}{c}0.044^{* * *} \\
(0.014)\end{array}$ \\
\hline year $=2011$ & $\begin{array}{c}0.128^{* * *} \\
(0.020)\end{array}$ & $\begin{array}{c}0.201^{* * *} \\
(0.036)\end{array}$ & $\begin{array}{c}0.089^{* * *} \\
(0.020)\end{array}$ & $\begin{array}{c}0.121^{* * *} \\
(0.026)\end{array}$ & $\begin{array}{c}0.090^{* * *} \\
(0.019)\end{array}$ \\
\hline year $=2012$ & $\begin{array}{c}0.086^{* * *} \\
(0.021)\end{array}$ & $\begin{array}{c}0.154^{* * *} \\
(0.040)\end{array}$ & $\begin{array}{l}0.036^{* *} \\
(0.017)\end{array}$ & $\begin{array}{c}0.066^{* * *} \\
(0.020)\end{array}$ & $\begin{array}{l}0.036^{* *} \\
(0.017)\end{array}$ \\
\hline year $=2013$ & $\begin{array}{c}0.161^{* * *} \\
(0.029)\end{array}$ & $\begin{array}{c}0.091^{* * *} \\
(0.026)\end{array}$ & $\begin{array}{l}0.067^{* *} \\
(0.026)\end{array}$ & $\begin{array}{c}0.160^{* * *} \\
(0.037)\end{array}$ & $\begin{array}{c}0.069^{* * *} \\
(0.024)\end{array}$ \\
\hline year $=2014$ & $\begin{array}{c}0.140^{* * *} \\
(0.015)\end{array}$ & $\begin{array}{c}0.138^{* * *} \\
(0.016)\end{array}$ & $\begin{array}{c}0.052^{* * *} \\
(0.009)\end{array}$ & $\begin{array}{c}0.124^{* * *} \\
(0.009)\end{array}$ & $\begin{array}{c}0.061^{* * *} \\
(0.013)\end{array}$ \\
\hline year $=2015$ & $\begin{array}{c}0.054^{* * *} \\
(0.019)\end{array}$ & $\begin{array}{c}0.067^{* * *} \\
(0.010)\end{array}$ & $\begin{array}{l}-0.007 \\
(0.021)\end{array}$ & $\begin{array}{c}0.047^{*} \\
(0.025)\end{array}$ & $\begin{array}{c}0.013 \\
(0.020)\end{array}$ \\
\hline year $=2016$ & $\begin{array}{c}0.000 \\
(.)\end{array}$ & $\begin{array}{c}0.000 \\
(.)\end{array}$ & $\begin{array}{c}0.000 \\
(.)\end{array}$ & $\begin{array}{c}0.000 \\
(.)\end{array}$ & $\begin{array}{c}0.000 \\
(.)\end{array}$ \\
\hline year $=2017$ & $\begin{array}{c}0.049^{* * *} \\
(0.016)\end{array}$ & $\begin{array}{c}-0.058^{* * *} \\
(0.013)\end{array}$ & $\begin{array}{c}0.051^{* * *} \\
(0.017)\end{array}$ & $\begin{array}{c}0.058^{* * *} \\
(0.016)\end{array}$ & $\begin{array}{c}0.064^{* * *} \\
(0.019)\end{array}$ \\
\hline year $=2018$ & $\begin{array}{c}0.057^{* * *} \\
(0.018)\end{array}$ & $\begin{array}{c}0.022 \\
(0.016)\end{array}$ & $\begin{array}{c}0.101^{* * *} \\
(0.031)\end{array}$ & $\begin{array}{l}0.083^{* *} \\
(0.032)\end{array}$ & $\begin{array}{c}0.086^{* * *} \\
(0.026)\end{array}$ \\
\hline $\begin{array}{l}\text { Observations } \\
\text { Adjusted } R^{2}\end{array}$ & $\begin{array}{c}384646 \\
0.063\end{array}$ & $\begin{array}{c}305095 \\
0.100\end{array}$ & $\begin{array}{c}256408 \\
0.046\end{array}$ & $\begin{array}{c}171385 \\
0.050\end{array}$ & $\begin{array}{c}234682 \\
0.047\end{array}$ \\
\hline
\end{tabular}

Notes: Column 1: West without June - Sept. Column 2: Midwest without June - Sept. Column 3: CA all months. Column 4: CA without June-Sept. Column 5: CA without Nov. The dependent variable is the natural $\log$ of $\mathrm{PM}_{2.5}$. The table reports the year fixed effects from the estimation of equation 1 . The regressions are weighted by county population in 2016. Monitor, month, and day of month fixed effects are estimated but not reported. Standard errors are clustered at the monitor level. 


\section{B Appendix: Calculation of Mortality}

To estimate the mortality burden imposed by the increased $\mathrm{PM}_{2.5}$ levels in nonattainment counties, the following calculations are performed. The functional form and parameter estimate governing the link between ambient $\mathrm{PM}_{2.5}$ and mortality risk $(\beta)$ are commonly used in the literature (United States Environmental Protection Agency (1999), United States Environmental Protection Agency (2010a)).

$$
\text { Deaths }_{a, i, t}=\operatorname{Pop}_{a, i, t} x M R_{a, i, t} x\left(1-1 /\left(\exp \left(\beta x\left(P M 2.5_{i, t}\right)\right)\right)\right)
$$

Totals deaths are the sum of (4) across age groups and nonattainment counties. We monetize the deaths from equation B.1 by applying the VSL uniformly across ages and counties. 